\begin{tabular}{llrr}
\hline \hline Volume: & 3 & E-ISSN: & $2655-1942$ \\
Number: & 1 & Terbitan: & Juni 2020 \\
Page : & $142-168$ & & \\
\hline
\end{tabular}

\title{
Batasan Hukum Keterbukaan Data Medis Pasien Pengidap Covid-19: Perlindungan Privasi VS Transparansi Informasi Publik
}

\author{
Rahandy Rizki Prananda \\ Fakultas Hukum, Universitas Diponegoro \\ Jl. Prof.H. Soedarto, S.H., Semarang \\ Email: rhd.rizki@gmail.com
}

\begin{abstract}
Abstrak
Persebaran infeksi virus Covid 19 telah mengalami peningkatan sejak temuan kasus pertama. Wacana pembukaan akses data rekam medis Pasien Positiv Covid 19 menimbulkan pro kontra dalam masyarakat. Artikel ini bertujuan untuk mengkaji perspektif sejumlah regulasi dalam memandang stasus data rekam medis, bentuk perlindungan huku dan implikasinya, serta solusi hukum untuk praktek yang diterapkan melalui studi komparatif dengan negara lain. Penelitian ini menggunakan metode yuridis normative dengan pendekatan undang-undang, konseptual dan perbandingan hukum. Hasil penelitian menunjukan bahwa Data rekam medis merupakan hak pribadi individu yang bersifat rahasia dan terbatas . Perlindungan hukum yang diberikan bagi data rekam medis pasien belum komprehensif. Guna mengantisipasi peningkatan penulara Virus Covid 19 , Praktek penggunaan data pribadi pasienp diterapakan oleh beberapa negara sesuai prinsip proporsionalitas, necesssitas dan purposive limitation.

Kata kunci : Data Medis, privasi , Covid 19, Keterbukaan
\end{abstract}

\begin{abstract}
The spread of Covid 19 virus infection has increased since the findings of the first case. The discourse of opening access to medical records data of Patient Positive Covid 19 raises the pros and cons in the community. This article aims to examine the perspectives of a number of regulations in viewing the status of medical record data, forms of legal protection and their implications, as well as legal solutions to practices implemented through comparative studies with other countries. This study uses normative juridical methods with approaches to law, conceptual and legal comparison. The results showed that medical record data is an individual's personal rights that are confidential and limited. Legal protection provided for patient medical record data is not yet comprehensive. To anticipate an increase in Covid Virus 19 transmission, the practice of using patient personal data is applied by several countries according to the principle of proportionality, necessity and purposive limitation.
\end{abstract}

Keyword: Medical Record, Privacy, Covid 19, Transparency 


\begin{tabular}{llrr}
\hline \hline Volume: & 3 & E-ISSN: & $2655-1942$ \\
Number: & 1 & Terbitan: & Juni 2020 \\
Page : & $142-168$ & & \\
\hline
\end{tabular}

\section{A. Latar Belakang Masalah}

Transparansi segala bentuk pemberitaan atas suatu peristiwa merupakan keharusan dan kelayakan untuk diketahui oleh masyarakat luas demi mendapatkan derajat informasi yang akurat pada era keterbukaan dewasa ini. Tuntutan ini secara tidak langsung menyebabkan tipisnya batas antara privasi pribadi dengan kepentingan Publik. Pemerintah berkewajiban menyediakan berita /informasi yang transparan dan akurat guna mencegah terjadinya disrupsi social dalam masyarakat. Digitalisasi pemberitaan yang terintegrasi secara langsung pada perangkat smartphone (telepon seluler pintar) dan alat elektronik lainnya turut mengubah tatanan peradaban manusia secara global.

Terkikis nya batasan jarak dan zona waktu menciptakan suatu efisiensi dalam berkomunikasi antar individu maupun kelompok. Namun di satu sisi, ada suatu permasalahan yang berpotensi menimbulkan gesekan dalam hal pengaturan perlindungan hukum dan limitasi penentuan skala prioritas antara ranah privat dengan domain public. Salah satu ranah yang menimbulkan persoalan hukum serius mengenai keterbukaan informasi yang mengandung dua kepentingan dari sisi perlindungan Hak privasi individu dan jaminan hak asasi public atas akses suatu pemberitaan yang menimbulkan implikasi bagi hajat hidup orang banyak. Penyediaan informasi rekam medis / kesehatan pasien menjadi isu hukum yang mengundang perdebatan terutama berkaitan dengan hal pembukaan data kondisi Kesehatan pasien yang menderita penyakit menular.

Wabah virus Covid-19 merupakan bencana penyakit yang menyerang negara-negara diseluruh dunia, tak terkecuali Indonesia. Penyakit ini pertama kali teridentifikasi pada wilayah Negara Kesatuan Republik Indonesia pertama kali pada akhir Maret 2020 , dimana dua warga asal Kota Depok, Jawa Barat menjadi subyek pertama yang tertular penyakit tersebut. Penularan Dua pasien positif Covid-19 berawal ketika salah satu di antaranya mengadakan kontak fisik dengan Warga Negara asal Jepang yang ternyata terbukti positif Covid-19 pada saat melakukan pemeriksaan di Malaysia. Pertemuan antara Pasien 01 dengan Warga Negara Jepang 
Law, Development \& Justice Review

\begin{tabular}{llrr}
\hline \hline Volume: & 3 & E-ISSN: & $2655-1942$ \\
Number: & 1 & Terbitan: & Juni 2020 \\
Page : & $142-168$ & & \\
\hline
\end{tabular}

pada acara dansa pada malam Valentine di Klub Amigos , Jakarta. ${ }^{1}$ Ternyata Warga Negara Jepang tersebut telah terjangkit Covid-19 dan menularkan nya pada Pasien 01 , kemudian Pasien 01 turut menularkan virus Covid-19 kepada Ibunya (Pasien 02). Hingga akhirnya keduanya menjalani test dinyatakan positif dan harus diisolasi di Rumah Sakit Sulianti Saroso.

Akhirnya Presiden Joko Widodo mengumumkan kasus perdana Covid-19 di Indonesia pada tanggal 2 Maret 2020. ${ }^{2}$ Semenjak kasus pertama yang telah teridentifikasi oleh Pemerintah, persebaran virus Corona pada sejumlah wilayah di Indonesia mulai terungkap dan bahkan mulai menunjukan kenaikan. Berdasarkan Data yang dirilis oleh Kementerian Kesehatan Republik Indonesia pada1,133,758 kasus dengan 62.784 kematian (CFR 5,5\%) di 204 Negara Terjangkit. ${ }^{3}$ Sedangkan untuk wilayah Indonesia per April 2020 , terdapat 1.242 orang yang diperiksa dengan hasil pemeriksaan yaitu 8.969 orang negatif (Termasuk ABK World Dream dan Diamond Princess), dan 2.273 kasus konfirmasi positif COVID-19 (164 sembuh dan 198 meninggal). ${ }^{4}$ Demi menanggulangi wabah penyakit ini, Pemerintah Republik Indonesia segera membentuk gugus tugas Satuan Penanganan Covid-19 dibawah kendali Badan Nasional Penanggulangan Bencana ( BNPB) dan menetapkan beberapa Langkah strategis antara lain : Pertama, Penanganan pasien yang terkena Covid-19, Kedua Pemberlakuan Pembatasan Sosial Berskala Besar (PSBB) dan menjaga kebersihan, Ketiga Penutupan akses penerbangan ke dan dari luar negeri. Puncaknya sejumlah Langkah tersebut direalisasikan dalam kebijakan tertulis oleh Presiden melalui penerbitan Keputusan Presiden Nomor 11 Tahun 2020 tentang Penetapan Kedaruratan Kesehatan Masyarakat terkait Covid-19 dan Peraturan Pemerintah Nomor 21 Tahun 2020 tentang Pembatasan Sosial Berskala Besar dalam Rangka Percepatan Penanganan Covid19.

1 https://health.detik.com/berita-detikhealth/d-4922758/kronologi-2-pasien-pertama-virus-corona-covid-19-diindonesia/1 diakses pada 30 Mei 2020 pukul 20.00 WIB

${ }^{2}$ Ibid

3 Data Kementerian Kesehatan RI tentang Persebaran Penyakit Virus Covid 19 per April 2020 dalam https://covid19.kemkes.go.id/situasi-infeksi-emerging/info-corona-virus/situasi-terkini-perkembangan-coronaviruscovid-19-6-april-2020/\#.XtUc_TozbIW yang diakses pada Sabtu 30 Mei 2020 pukul 23.00 WIB ${ }^{4}$ Ibid 


\begin{tabular}{llrr}
\hline \hline Volume: & 3 & E-ISSN: & $2655-1942$ \\
Number: & 1 & Terbitan: & Juni 2020 \\
Page : & $142-168$ & & \\
\hline
\end{tabular}

Di tengah pelaksanaan penanggulangan dan pencegahan wabah Covid-19 terdapat pro kontra berkenaan dengan pembukaan transparansi data pasien penderita Covid-19 menjadi polemic bagi pembuat kebijakan dan masyarakat . Bagi pihak yang mendukung keterbukaan data pribadi pasien penderita Covid-19 secara komprehensif beralasan bahwa Tindakan tersebut dapat membantu dalam mengantisipasi penularan secara terorganisasi. Namun penolakan juga datang dari kalangan yang kontra dengan upaya ini, dikarenakan hal tersebut berpotensi menimbulkan diskriminasi dan persekusi sepihak dari masyarakat terhadap pasien serta keluarga dan orang terdekat nya. Sebagaimana peristiwa yang terjadi pada pasien 01 dan 02 dimana data pribadi keduanya disebarkan oleh oknum tak bertanggungjawab meliputi domisili, foto anggota keluarga , pekerjaan hingga lokasi kerja yang bersangkutan.

Penyediaan informasi data Pasien Covid-19 secara transparan dan menyeluruh oleh pihakpihak yang terlibat dalam penanganan wabah ini merupakan kewajiban yang ditetapkan oleh Undang-Undang dan wajib dilaksanakan . Hal ini sebagaimana dituangkan dalam Pasal 57 ayat 2 UU. No.36 tahun 2009 (selanjutnya disebut dengan UU Kesehatan Nasional) menyatakan bahwa hak atas rahasia kondisi pribadi dianggap tidak berlaku dalam hal perintah Undang-Undang dan kepentingan masyarakat. Kondisi tersebut menimbulkan benturan persoalan hukum yang cukup genting antara pelindungan hak privat dengan pemenuhan kepentingan publik, Masalah keamanan rekam media harus ditangani secara berbeda dan keterbukaan kepada publik memunculkan tantangan bagi eksistensi Hak asasi pribadi. Privasi medis juga dapat merujuk pada interaksi antara pasien dan penyedia saat berada di fasilitas medis, ${ }^{5}$ data rekam medis pasien merupakan bagian hak asasi yang melekat pada diri individu yang bersangkutan dan bersifat rahasia sehingga perlu adanya suatu perlindungan hukum.

Memperhatikan pada problematika pengutamaan pelindungan data rekam medis sebagai bagian hak asasi manusia dalam ranah privat dengan kepentingan public guna mencegah penyebaran wabah pandemic Covid-19, Artikel ini akan mengkaji beberapa hal diantaranya

\footnotetext{
${ }^{5}$ Chan Khung Wang . 2015. Security and privacy of Personal Health Record, Electronic Medical Record and Health Information. Problems and Perspectives in Management, Volume 13, Issue 4, 2015 p. 19
} 


\begin{tabular}{llrr}
\hline \hline Volume: & 3 & E-ISSN: & $2655-1942$ \\
Number: & 1 & Terbitan: & Juni 2020 \\
Page : & $142-168$ & & \\
\hline
\end{tabular}

Pertama, Identifikasi perspektif hukum nasional dalam memandang pembukaan data Kesehatan pasien sebagai bentuk transparansi informasi . Kedua, untuk mengkaji perlindungan yang diberikan kepada individu pemilik rekam medis dan Implikasinya secara hukum pasca dibukanya informasi yang bersangkutan oleh pihak -pihak yang tidak berwenang ke khalayak masyarakat, Ketiga , memberikan evaluasi masukan kepada Pemerintah dengan melalui studi komparatif.

\section{B. Metode Penelitian}

Artikel ini menerapkan metode penelitian yuridis normative. Penelitian Hukum Normatif adalah penelitian yang hanya menggunakan sumber data-data sekunder, yaitu peraturan perundang- undangan, putusan pengadilan, teori-teori hukum, dan doktrin ahli hukum terkemuka. ${ }^{6}$ Pendekatan yang digunakan oleh penulis antara lain Pertama pendekatan perundang-undangan (Statute Approach), pendekatan konseptual (Conceptual Approach) dan Pendekatan analitis ( Analytical approach). Peneliti melakukan inventaris data sekunder yang terdiri dari bahan hukum primer . bahan hukum sekunder dan tersier yang mempunyai korelasi dengan topik permasalahan yang akan diteliti. Spesifikasi penelitian yang digunakan bersifat preskriptif-analitis. Kemudian keseluruhan data yang dihimpun akan diseleksi untuk kemudian dianalisa secara kualitatif.

\section{Hasil Penelitian dan Pembahasan}

\section{Perspektif Berbagai Aturan Hukum Nasional Terhadap Hak atas Informasi Publik Pada Data Rekam Medis Pasien Penderita Covid-19}

Sebelum menguraikan kedudukan data rekam medis pasien dalam berbagai legal instrument yang berlaku secara nasional, Maka terlebih dahulu akan diuraikan mengenai Konsepsi tentang Hak dan informasi. Konteks Hak menurut Sudikno Mertokusumo diartikan sebagai kepentingan yang dilindungi, sedangkan kepentingan didefinisikan sebagai perorangan atau kelompok yang diharapkan untuk dipenuhi. Kepentingan pada hakikatnya mengandung

\footnotetext{
${ }^{6}$ Abdul Kadir Muhammad. 2015 . Hukum Dan Penelitian Hukum. Bandung : PT. Citra Aditya
} 


\begin{tabular}{llrr}
\hline \hline Volume: & 3 & E-ISSN: & $2655-1942$ \\
Number: & 1 & Terbitan: & Juni 2020 \\
Page : & $142-168$ & & \\
\hline
\end{tabular}

kekuasaan yang dijamin dan dilindungi oleh hukum dalam melaksanakannya ${ }^{7}$ Mencermati definisi tersebut, maka hak dapat dikualifikasikan sebagai sesuatu hal yang bersifat melekat secara hakiki pada diri manusia dan implementasinya diterapkan pada lingkup kebebasan dan persamaan pada saat menjalankan interaksi dengan sesame individu maupun lembaga.

Sementara itu pengertian informasi, kata informasi berasal dari kata informare yang berarti memberi bentuk dan to inform yang mempunyai arti memberitahukan. Dari dua definisi bersangkutan, Jadi informasikan dapat diartikan sebagai pemberitahuan atas suatu hal tertentu agar dapat membentuk pandangannya atas sesuatu yang disampaikan berdasarkan pengetahuannya. UU. No.14 tahun 2008 tentang keterbukaan Informasi Publik ( Selanjutnya disebut UU Keterbukaan Informasi Publik) mendefinisikan informasi sebagai keterangan, pernyataan, gagasan, dan tanda-tanda yang mengandung nilai, makna, dan pesan, baik data, fakta maupun penjelasannya yang dapat dilihat, didengar, dan dibaca yang disajikan dalam berbagai kemasan dan format sesuai dengan perkembangan teknologi informasi dan komunikasi secara elektronik ataupun non elektronik. Regulasi ini menguraikan konteks informasi publik sebagai informasi yang dihasilkan, disimpan, dikelola, dikirim, dan/atau diterima oleh suatu badan publik yang berkaitan dengan penyelenggara dan penyelenggaraan negara dan/atau penyelenggara dan penyelenggaraan badan publik lainnya yang sesuai dengan Undang-Undang ini serta informasi lain yang berkaitan dengan kepentingan publik.

Pada system hukum nasional, sejumlah regulasi menggolongkan Informasi atas Kesehatan ke dalam dua ranah yaitu aspek hukum public dan aspek hukum privat. Informasi Kesehatan dalam lingkup hukum public terdiri dari dua macam yaitu informasi Kesehatan yang bersifat umum dan khusus. Informasi public terkait Kesehatan yang bersifat umum terdiri dari system informasi layanan rumah sakit yang berupa biaya, jenis dan mekanisme pelayanan, standar operasional, fasilitas pelayanan dan sistem pembiayaan. Sedangkan informasi publik atas Kesehatan yang bersifat khusus meliputi Informasi hasil laporan penelitian atas suatu penyakit , program pencegahan dan penanggulangan wabah penyakit, data perkembangan jenis penyakit

\footnotetext{
${ }^{7}$ Sudikno Mertokusumo, Mengenal Hukum Suatu Pengantar, Yogyakarta: Liberty, 2005, hlm. 43
} 


\begin{tabular}{llrr}
\hline \hline Volume: & 3 & E-ISSN: & $2655-1942$ \\
Number: & 1 & Terbitan: & Juni 2020 \\
Page : & $142-168$ & & \\
\hline
\end{tabular}

menular, pola penyebaran atau penularan suatu penyakit, area persebaran wabah penyakit dan statistic suatu peristiwa atau yang mendeskripsikan pola penyebaran penyakit . sejumlah lingkup jenis informasi Kesehatan yang bersifat public diatas wajib dibuka untuk umum sebagaimana diamanatkan oleh Undang-Undang .

Sejumlah alasan penting yang mendasari urgensi keterbukaan informasi kepada public wajib diperhatikan antara lain : Pertama, era globalisasi saat access to government records information terjadi hampir di seluruh dunia, sehingga pemerintah dituntut untuk mulai membuka diri terhadap setiap akses informasi yang sangat diperlukan oleh public. ${ }^{8}$ Kedua, Implikasi penegakan Hak asasi Manusia yang membutuhkan keterbukaan informasi melalui pelibatan masyarakat secara aktif demi mengontrol kebijakan Pemerintah. Ketiga, Kemajuan teknologi informatika yang memudahkan masyarakat mendapatkan berita secara cepat dan efisien. Keempat, Kebijakan transparansi informasi menjadi landasan hukum dalam menciptakan good governance. Dari sisi hukum publik, pengaturan Informasi public dirumuskan pada sejumlah Undang-Undang diantaranya adalah UU Keterbukaan Informasi Publik dan UU No. 36 tahun 2009 tentang Kesehatan ( berikutnya disebut dengan UU Kesehatan ). Transparansi Hak akses masyarakat atas informasi Kesehatan diatur dalam Pasal 169 UU Kesehatan yang menyatakan bahwa :

"Pemerintah memberikan kemudahan kepada masyarakat untuk memperoleh akses terhadap informasi kesehatan dalam upaya meningkatkan derajat kesehatan masyarakat."

Pada masa pandemic Covid-19 menimbulkan dilemma bagi Pemerintah Negara-negara di dunia terutama dalam hal penghentian penularan wabah penyakit ini . Ketidakpastian mengenai penemuan vaksin sebagai obat penyakit Virus Covid-19 menambah beban ancaman bagi stabilitas suatu negara tidak hanya dari sisi Kesehatan, namun juga gangguan di bidang sosial ekonomi. Guna mengantisipasi efek sistemik atas terjadinya wabah ini , setiap negara berusaha mengeluarkan kebijakan non -medis yang berupa "Vaksin Sosial”. Vaksin Sosial merupakan

\footnotetext{
${ }^{8}$ Endang Wahyati Yustina . 2014. Hak atas Informasi Publik dan Hak atas Rahasia Medis : Problem Hak Asasi Manusia dalam Pelayanan Kesehatan . Padjajaran Jurnal Ilmu Hukum. Vol 1 No.2 tahun 2014
} 


\begin{tabular}{llrr}
\hline \hline Volume: & 3 & E-ISSN: & $2655-1942$ \\
Number: & 1 & Terbitan: & Juni 2020 \\
Page : & $142-168$ & & \\
\hline
\end{tabular}

Langkah dan strategi Pemerintah dengan cara memberikan informasi serta data penting untuk meningkatkan kesadaran masyarakat untuk menjalani hidup sehat di tengah merebak nya wabah penyakit Covid19.

Pemberian informasi serta literasi yang transparan dan aktual kepada publik harus diaplikasikan oleh Pemerintah dalam mengontrol persebaran pandemic Covid-19. Langkahlangkah antisipatif seperti perkembangan penanganan kasus dengan menggunakan terapi plasma darah dari pasien yang sudah sembuh dari Covis-19, tingkat kasus positif dan negative pengidap Covid-19, jumlah angka kematian, populasi pasien yang sembuh, metode pengurangan rasio penyebaran, prosedur penanganan dan jenazah penderita Covid-19 hingga lamanya masa karantina. Poin -poin informasi yang bersifat akurat, terbuka dan akuntabel diharapkan dapat digunakan oleh Pemerintah dalam menekan resiko melalui kebijakan-kebijakan yang tepat guna mengurangi peningkatan jumlah masyarakat yang mengidap Virus Covid-19 .

Dalam perspektif pemenuhan hak pasien selaku konsumen pada penyelenggaraan jasa layanan Kesehatan, Keterbukaan Hak atas akses informasi Kesehatan turut menjadi bagian focus permasalahan yang dianggap prioritas utama. Hal ini sebagaimana diatur pada UU. No.8 tahun 1999 tentang Perlindungan Konsumen dan UU. No. 44 tahun 2009 tentang Rumah Sakit. Menurut ketentuan Pasal 4 ayat (3) UU. Perlindungan Konsumen yang mengakomodasi secara jelas bagi Konsumen dalam hak untuk memperoleh informasi yang benar, jelas, dan jujur mengenai kondisi dan jaminan barang dan atau jasa. Jika dikaitkan dengan ketentuan diatas dengan pemenuhan ha katas informasi Kesehatan yang bersifat public, maka secara tidak langsung dapat dikatakan bahwa masyarakat selaku konsumen / pasien pengguna jasa Kesehatan berhak mendapatkan informasi yang jelas dan jujur dalam menerima layanan Kesehatan oleh penyelenggara.

Kewajiban transparansi atas pemberian informasi Kesehatan juga dibebankan pada Rumah Sakit sebagai entitas penyedia layanan Kesehatan. Dalam ketentuan pasal 29 ayat (1) UU.No.44 tahun 2009 tentang Rumah Sakit dinyatakan bahwa Rumah sakit diharuskan menyediakan informasi yang benar atas pelayanan yang diberikan kepada masyarakat. Ruang 


\begin{tabular}{llrr}
\hline \hline Volume: & 3 & E-ISSN: & $2655-1942$ \\
Number: & 1 & Terbitan: & Juni 2020 \\
Page : & $142-168$ & & \\
\hline
\end{tabular}

lingkup informasi yang wajib diberikan secara akurat dan transparan antara lain jenis layanan; transparansi anggaran; kemudahan akses; dan kewajiban publik lainnya berkenaan dengan statusnya sebagai badan layanan publik.

Keterbukaan data informasi kepada masyarakat pada masa Pandemic Covid-19 sebagaimana diatur pada beberapa aturan Undang-Undang diatas merupakan tindak lanjut pengaturan hak Asasi Manusia yang terkandung dalam UUD NRI 1945. Berdasarkan ketentuan Pasal 28 E dan 28 F UUD NRI 1945 memberikan jaminan bagi seluruh warga negara Indonesia untuk memiliki, memperoleh dan menyebarluaskan berita informasi kepada masyarakat. Bila dikaitkan dengan penanganan wabah Covid-19, Pemenuhan Kebutuhan informasi oleh Pemerintah bagi masyarakat akan data yang valid, akurat dan terus diperbaharui sesuai kondisi terkini serta mitigasi resiko wajib dilaksanakan tanpa terkecuali. Keterbukaan dan koordinasi Pemerintah Republik Indonesia pengiriman informasi secara terintegrasi dengan Pemerintah Daerah menjadi kunci dalam mengontrol penyebaran Covid-19 agar tidak semakin masif. Selain itu akurasi dan penyampaian informasi yang akuntabel tentang wabah Covid-19 dapat dijadikan sebagai rambu-rambu pencegahan penerimaan informasi yang asimetris yang membahayakan masyarakat diantaranya prosedur penggunaan disinfektan, penggunaan obatobatan suplemen yang tidak disarankan dan Tindakan penimbunan alat-alat Kesehatan .

Sedangkan jenis informasi Kesehatan yang bersifat privat. Lingkup rekam medis terdiri dari data dan kondisi Kesehatan pasien baik yang dirumuskan dalam data rekam medis maupun diketahui oleh pihak penyelenggaraan layanan Kesehatan baik rumah sakit, klinik maupun dokter. Data rekam medis pasien dikualifikasikan ke dalam data pribadi yang bersifat sensitive. Hal itu tidak terlepas berkenaan dengan potensi resiko hukum yang dikhawatirkan dapat terjadi seperti kompilasi, akses dan penyebarluasan data rekam medis tersebut kepada pihak lain yang tidak mempunyai kompetensi tanpa sepengetahuan dan persetujuan dari si pasien sendiri. 
Law, Development \& Justice Review

\begin{tabular}{llrr}
\hline \hline Volume: & 3 & E-ISSN: & $2655-1942$ \\
Number: & 1 & Terbitan: & Juni 2020 \\
Page : & $142-168$ & & \\
\hline
\end{tabular}

Contohnya dapat dimanfaatkan secara ekonomi oleh industri penyedia jasa lainnya seperti industri obat - obatan, industri asuransi sehingga akan terjadi yang disebut dengan direct selling. ${ }^{9}$

Ketentuan Pasal 1 ayat 1 Peraturan Menteri Kesehatan Republik Indonesia No. 269 tahun 2008 tentang Rekam Medis dinyatakan bahwa rekam medis merupakan catatan dan dokumen yang berisikan identitas pasien, pemeriksaan, pengobatan, Tindakan dan pelayanan lain diberikan kepada pasien . Informasi yang tercantum dalam rekam medis bersifat rahasia. Hal ini dikarenakan konten rekam medis menjelaskan hubungan yang khas antara pasien dan dokter sehingga wajib dilindungi dari pembocoran sesuai dengan kode etik kedokteran dan peraturan perundang-undangan yang berlaku. ${ }^{10}$ Unsur kerahasiaan dalam data rekam medis terdiri dari laporan yang merupakan hasil pemeriksaan pasien yang tidak diperbolehkan untuk disebarluaskan kepada pihak-pihak yang tidak berwenang, karena menyangkut pribadi pasien yang bersangkutan. Pada prinsipnya, pasien mempunyai hak untuk mendapatkan kerahasiaan dan privasi atas penyakit yang dialaminya Hal ini sebagaimana diatur dalam Pasal 32 huruf i UU. No. 44 tahun 2009 tentang Kesehatan.

Data rekam medis secara principal terdiri dari dua aspek yaitu informasi yang bersifat rahasia dan informasi yang tidak mengandung kerahasiaan ${ }^{11}$. Informasi yang bersifat rahasia terdiri dari laporan atau hasil pemeriksaan dari keadaan Kesehatan pasien, sehingga konten dokumen ini tidak diperbolehkan untuk dibuka maupun disebarluaskan kepada pihak-pihak yang tidak mempunyai kewenangan. Pemberitahuan menyangkut penyakit pasien kepada pasien/keluarga menjadi tanggung jawab dokter pasien, pihak lain tidak memiliki hak sama sekali. Sementara itu, informasi yang tidak mengandung kerahasiaan antara lain identitas dan informasi non medis. Informasi rekam medis milik pasien penderita Covid-19 merupakan jenis

\footnotetext{
${ }^{9}$ Sinta Dewi Rosadi . 2016. Implikasi Penerapan Program E-Health Dihubungakn Dengan Perlindungan Data Pribadi Jurnal Arena Hukum Volume 9, Nomor 3, Desember 2016 . hal 407

${ }^{10}$ Anny Retnowati. 2006. “Tinjauan Hukum Terhadap rekam Medis," JUSTITIAETPAX, Juni (26), No. 1, hal 6

${ }^{11}$ Anny Retnowati. 2013. Politik Hukum dalam Menata Rekam Medis ssebagai alt perlindungan Hukum Terhadap Rumah Sakit, Pasien dan Dokter. Jurnal Yustisia Vol.2 No.2 Mei -Agustus 2013 hal 145
} 


\begin{tabular}{llrr}
\hline \hline Volume: & 3 & E-ISSN: & $2655-1942$ \\
Number: & 1 & Terbitan: & Juni 2020 \\
Page : & $142-168$ & & \\
\hline
\end{tabular}

informasi yang bersifat privat. Data pribadi pasien merupakan informasi yang dikecualikan untuk diungkap kepada masyarakat luas.

Ketentuan tersebut diatur dalam Pasal 17 h UU Keterbukaan Informasi Publik serta Pasal 57 ayat (1) UU Nomor 36 Tahun 2009 tentang Kesehatan yang menyatakan bahwa :

setiap orang berhak atas rahasia kondisi kesehatan pribadinya yang telah dikemukakan kepada penyelenggara pelayanan kesehatan.

Konten Informasi yang berisi rekam medik maupun data pribadi non medis pasien Covid-19 menjadi informasi yang dikecualikan bersifat ketat dan terbatas untuk dipublikasikan kepada masyarakat . Data ini hanya dapat dibuka atas ijin si pemiliknya atau berdasarkan perintah aturan perundang-undangan, jika ada yang melanggar ketentuan ini dapat dikenakan sanksi hukum sesuai aturan perundang- undangan yang berlaku . Berdasarkan uraian penjelasan diatas dapat dinyatakan bahwa informasi mengenai Kesehatan yang bersifat public dapat diakses oleh masyarakat secara terbuka, karena informasi tersebut tergolong ke dalam bagian Hak dasar social untuk mengakses layanan Kesehatan. Namun tidak demikian dengan data rekam medis yang secara kontekstual mengandung Hak individual yang bersifat rahasia. Keterbukaan akses data rekam medis sangat dibatasi secara hukum.

\section{Perlindungan terhadap Rekam Medik Pasien Penderita Covid-19 dan Implikasinya atas Pelanggaran Atas Kerahasiaan Data Pasien}

\subsection{Perlindungan Hukum Terhadap Data Rekam Medis Pasien Covid-19 dan Implikasi Pelanggaran atas Kerahasiaan Data Medis}

Pembukaan informasi identitas pribadi dan data rekam medis milik Pasien positif Covid19 menimbulkan perdebatan dalam masyarakat. Permohonan untuk mengungkap data pasien positif Covid-19 secara total bagi sebagian kelompok dinilai sangat diperlukan, agar dapat menahan laju tingkat penularan kepada masyarakat. Dengan pembukaan informasi medis milik pasien Covid-19 diharapkan masyarakat dapat mengetahui tentang subyek, lokasi domisili dan 
Law, Development \& Justice Review

\begin{tabular}{llrr}
\hline \hline Volume: & 3 & E-ISSN: & $2655-1942$ \\
Number: & 1 & Terbitan: & Juni 2020 \\
Page : & $142-168$ & & \\
\hline
\end{tabular}

Riwayat interaksi sosial pasien atau terduga positif Covid-19. Para pendukung pengungkapan data rekam medis memiliki pandangan bahwa transparansi dibutuhkan sebagai sarana proteksi lebih dini terhadap resiko penularan dengan melakukan pembatasan jarak. Argumen ini didasarkan pada peningkatan jumlah subyek yang diindikasikan tertular virus Covid-19 tiap bulannya yang diterbitkan oleh Instansi yang berwenang .

\section{Grafik 1}

\section{Peta Persebaran Kasus Covid-19 di Indonesia Per 30 Mei 2020}

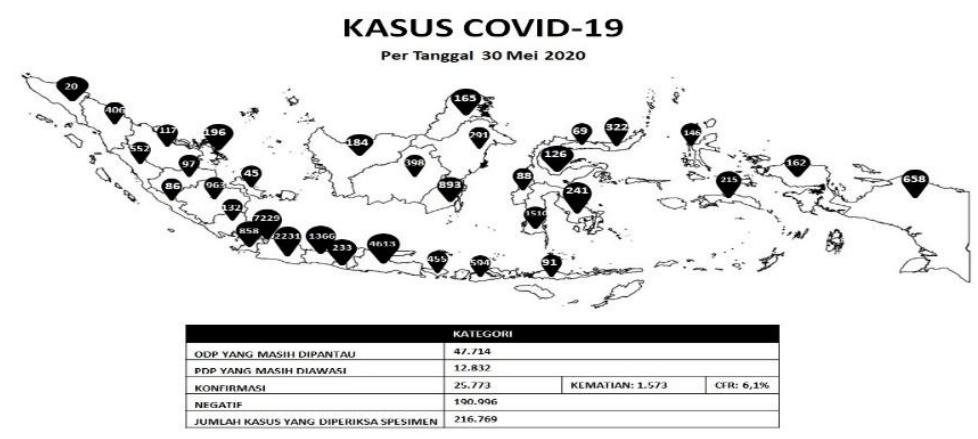

Sumber Kementerian Kesehatan RI

Menurut data yang dirilis oleh Kementerian Kesehatan Republik Indonesia, total kasus konfirmasi COVID-19 global per tanggal 30 Mei 2020 adalah 5.817.385 kasus dengan 362.705 kematian (CFR 6,2\%) di 215 Negara yang terjangkit penyakit ini Daftar negara terjangkit COVID-19 dapat bertambah setiap harinya mengikuti perkembangan data dan informasi yang didapatkan di Situation Report WHO. Sedangkan Kementerian Kesehatan RI menemukan bahwa terdapat lebih dari 5.701.337 kasus dengan 357.688 kematian (CFR 6,3\%) di 215 Negara yang terjangkit. Sedangkan untuk wilayah Indonesia, terdapat 26,940 kasus positif Covid-19 yang menyebabkan korban meninggal dunia sebanyak 1,641 orang. Narasi data yang terlampir diatas

12 Data Persebaran Virus Covid 19 Mei 2020 yang diakses dari https://covid19.kemkes.go.id/situasi-infeksiemerging/info-corona-virus/situasi-terkini-perkembangan-coronavirus-disease-covid-19-31-mei2020/\#.XtcJYTozbIU pada 31 Mei 2020 pukul 08.00 WIB 
Law, Development \& Justice Review

\begin{tabular}{llrr}
\hline \hline Volume: & 3 & E-ISSN: & $2655-1942$ \\
Number: & 1 & Terbitan: & Juni 2020 \\
Page : & $142-168$ & & \\
\hline
\end{tabular}

turut mendorong semakin derasnya permintaan kubu pendukung pembukaan data pasien dalam memperjuangkan aspirasinya dalam penanggulangan Covid-19.

Namun di satu sisi, pengungkapan data pasien positif Covid-19 turut menimbulkan konsekuensi secara hukum, berupa pelanggaran atas bagian dari hak asasi manusia yang bersifat sensitive. Informasi data medis pasien positive Covid-19 harus dilindungi dan dikesampingkan untuk dibuka kepada public. Sejumlah resiko berpotensi terjadi akibat pembukaan data medis pribadi terhadap Orang Dalam Pemantauan (ODP), Pasien Dalam Pengawasan (ODP), Pasien positif dan Pasien sembuh oleh para pihak yang tidak punya kompetensi menimbulkan pelanggaran hak asasi individual. Stigma negative yang disematkan pada keempat jenis subyek diatas merupakan pembawa virus. Sehingga banyak dari mereka yang diusir dar tempat tinggal dan Bahkan bagi yang telah meninggal mendapatkan penolakan ketika akan dimakamkan.

Pada masa penanggulangan Covid-19, dalam praktek di lapangan beberapa kasus yang terjadi seringkali penyelenggara jasa pelayanan kesehatan harus berhadapan dengan dua pilihan yaitu Pertama, Dokter atau petugas medis tetap memberikan informasi tentang kondisi Kesehatan seorang pasien sebagai peringatan dan pencegahan agar masyarakat terhindar dari penularan wabah penyakit. Kedua, Dokter atau petugas medis tetap berpedoman pada regulasi dengan tetap menjaga rahasia medis pasiennya. Jika mengacu pada aturan untuk mengungkap data rekam medis pasien positive Covid-19 secara normative dalam UU. Keterbukaan Informasi Publik, Maka informasi medis Pasien bersifat rahasia dan terbatas artinya kedudukannya secara hukum merupakan jenis informasi yang mendapatkan pengecualian agar tidak disebarluaskan kepada masyarakat. Ketentuan ini juga dipertegas dalam Peraturan Menteri Kesehatan Republik Indonesia Nomor 269 Tahun 2008 yang mengatur bahwa sarana pelayanan kesehatan bertanggung jawab terhadap rekam medis. Pihak penyedia pelayanan kesehatan diwajibkan membuat atau mencatat semua kejadian terkait dengan layanan yang dilakukan terhadap pasien; mengelola sebaik-baiknya; dan menjaga kerahasiaan nya.. 


\begin{tabular}{llrr}
\hline \hline Volume: & 3 & E-ISSN: & $2655-1942$ \\
Number: & 1 & Terbitan: & Juni 2020 \\
Page : & $142-168$ & & \\
\hline
\end{tabular}

Memperhatikan pada hal tersebut, maka dapat disimpulkan bahwa data kesehatan pasien bukan termasuk informasi yang wajib dijaga dan dilindungi hanya bisa dibuka atas ijin pasien penderita Covid-19 yang bersangkutan atau berdasarkan ketentuan peraturan perundangundangan dapat disampaikan kepada publik. Rahasia kedokteran/rahasia medis merupakan hak pasien yang harus dihormati. Hak Rahasia kedokteran berkaitan dengan kondisi rekam medis pasien menjadi Batasan yang tidak boleh dilanggar dalam mendapatkan Hak akses atas informasi kesehatan. Hak privasi dalam data rekam medis pasien merupakan bagian dari hak dasar individual ( the rights to self determination) dalam pelayanan kesehatan. Data rekam medis merupakan obyek hukum dalam hukum Kesehatan yang merupakan bagian dari Konsep Trilogi Rahasia Kedokteran. Dalam Trilogy Rahasia kedokteran meliputi suatu rangkaian hubungan yang saling berkorelasi antara Tindakan medis yang satu dengan yang lain. Hubungan layanan medis / terapeutik terdiri dari tiga unsur yaitu informed consent, medical record dan rahasia medis.

Hubungan terapeutik antara dokter dan pasien diawali dengan pemberian hak atas informasi awal terkait kondisi medis pasien. Kemudian dokter selaku bagian perangkat layanan Kesehatan wajib meminta dan mendapatkan persetujuan dari pasien yang bersangkutan(informed consent). Intinya informed consent merupakan Tindakan medis yang diawali pemberian informasi dari dokter yang memberikan pelayanan medis dan diakhiri dengan persetujuan pasien untuk dilakukan tindakan medis Informasi ini merupakan Hak yang wajib diketahui oleh Pasien. Sehingga wajib dilaksanakan meskipun pasien tidak meminta. Dalam Peraturan Menteri Kesehatan No. 290 tahun 2008 tentang Rekam Medis, Tindakan inform consent wajib diselenggarakan oleh dokter dengan itikad baik, jujur dan tidak mengintimidasi pasien serta wajib diuraikan selengkap-lengkapnya mengenai dampak positif dan negative Tindakan medis yang akan diambil oleh dokter.

Pihak dokter dan Petugas Medis yang merawat Pasien Positive Covid-19 mempunyai kewajiban membuat medical records atas segala hal Tindakan yang dilakukan untuk pasien yang ditanganinya. Konten rekam medis berisi ringkasan kontak pasien dengan sarana pelayanan 


\begin{tabular}{llrr}
\hline \hline Volume: & 3 & E-ISSN: & $2655-1942$ \\
Number: & 1 & Terbitan: & Juni 2020 \\
Page : & $142-168$ & & \\
\hline
\end{tabular}

Kesehatan yang terdiri dari sejumlah komponen yaitu data pribadi pasien, pemeriksaan, jenis pengobatan, Tindakan yang diambil dokter serta korespondensi demi keberlanjutan layanan control dan konsultasi. Ringkasan catatan medis pasien yang tertuang dalam medical record dapat disusun secara manual dengan tulisan tangan lengkap dan jelas dan atau/ data elektronik berdasarkan ketentuan peraturan perundang-undangan.

Peranan rekam medis juga berfungsi sebagai kompilasi fakta atas kondisi Kesehatan dan penyakit yang diderita oleh Pasien. sehingga data rekam medis pasien akan memuat dua hal antara lain : Dokumentasi perbandingan perkembangan penyakit yang diderita pasien pada kondisi yang lampau dengan saat ini dan dokumentasi tertulis tentang Tindakan dokumen yang belum, sedang dan akan dilakukan oleh dokter. Memperhatikan dua komponen diatas, setidaknya substansi dirangkum dalam rekam medis pasien harus memuat tiga hal antara lain : a. Siapa (Who) menyangkut keterangan identitas pasien dan Siapa (Who) dokter yang merawat/memberikan tindakan medis. b. Apa (What) keluhan pasien, Kapan (When) itu mulai dirasakan, Mengapa (Why) atau sebab terjadinya dan Bagaimana (How) tindakan medis yang diterima pasien. c. Hasil atau dampak (Outcome) dari tindakan medis dan pengobatan yang sudah diterima pasien. Data yang mengandung ketiga unsur diatas harus tidak boleh salah, akurat dan tidak boleh tertinggal, karena data tersebut berdampak fatal bagi keselamatan jiwa pasien jika terjadi kesalahan. ${ }^{13}$ Tanggung jawab dan kewajiban penyelenggara layanan Kesehatan untuk melakukan Rekam medis diatur dalam Pasal 29 Ayat (1) huruf h UU No 44 Tahun 2009 Tentang Rumah Sakit yang menyatakan bahwa :

"Setiap Rumah Sakit mempunyai kewajiban: menyelenggarakan Rekam Medis ."

Konteks penyelenggaraan Rekam medis sebagaimana diuraikan pada pasal diatas , dilaksanakan sesuai dengan standar internasional yang akan disesuaikan secara bertahap. Jika ketentuan ini dilanggar oleh penyelenggara layanan Kesehatan, maka akan dikenakan

\footnotetext{
${ }^{13}$ Sudjana . 2016 . Aspek Hukum Rekam Medis atau Rekam Medis Elekronik Sebagai Alat Bukti Dalam Transksi Elektronik. Jurnal Veritas et Justitia Volume 3 Nomor 2 , Penerbit ; Fakulats Hukum Universitas Katolik Parahyangan hal 363
} 


\begin{tabular}{llrr}
\hline \hline Volume: & 3 & E-ISSN: & $2655-1942$ \\
Number: & 1 & Terbitan: & Juni 2020 \\
Page : & $142-168$ & & \\
\hline
\end{tabular}

sanksi administrative berupa teguran, teguran tertulis, denda dan pencabutan izin rumah sakit. Aturan ini turut dipertegas dalam ketentuan Pasal 70 dan Pasal 71 UU No. 36 Tahun 2014 Tentang Tenaga Kesehatan menekankan bahwa Setiap Tenaga Kesehatan yang melaksanakan pelayanan kesehatan perseorangan wajib membuat Rekam medis Penerima Pelayanan Kesehatan yang harus segera dilengkapi setelah Penerima Pelayanan Kesehatan selesai menerima pelayanan kesehatan".

Setiap Rekam Medis Pasien harus melampirkan nama, waktu, dan tanda tangan atau paraf Tenaga Kesehatan yang memberikan pelayanan atau tindakan. Selanjutnya dokumen tersebut akan disimpan oleh penyelenggara jasa kesehatan. Pihak pasien, pihak keluarga pasien dan orang yang dikuasakan dapat meminta Salinan atas data rekam medis tersebut. Status Hukum kepemilikan Rekam medis dibedakan menjadi dua yaitu berkas dan isi. Pasien mempunyai hak milik atas konten rekam medis, sedangkan dokumen berada dibawah kekusaan dan dimiliki oleh penyelenggara layanan Kesehatan. Meskipun sesungguhnya dua hal tersebut merupakan satu kesatuan. Selain berkewajiban membuat bukti rekaman medis, pihak penyelenggara juga diharuskan melakukan penyimpanan demi keamanan dokumen tersebut dalam suatu warkat. Metode penyimpanan dalam bentuk warkat dibagi ke dalam dua jenis yaitu penyimpanan warkat yang masih berproses atau belum selesai (file pending) dan penyimpanan warkat yang sudah diproses (file tetap).Prosedur penyimpanan berkas rekam medis diatur berdasarkan Langkahlangkah sistematis yang terdiri dari ; Pemeriksaan, mengindeks, pemberian tanda, penyeleksian data dan penyimpanan. Durasi penyimpanan data pasien rawat inap di rumah sakit adalah selama 5 tahun sejak tanggal terakhir pasien dirawat inap atau dipulangkan .

Ringkasan medis baru dapat dimusnahkan pasca 5 tahun, namun ringkasan pulang dan dokumen persetujuan medis tetap harus disimpan unruk 10 tahun ke depan dihitung sejak tanggal dibuatnya ringkasan tersebut. Kewenangan penyimpanan rekam medis pasien dan ringkasan pulang hanya dapat dilakukan oleh petugas yang ditunjuk oleh pimpinan penyelenggara Kesehatan. Sedangkan penyimpanan data rekam medis pasien oleh Lembaga penyelenggara jasa layanan kesehatan non rumah sakit (klinik dan puskesmas) wajib kurang-kurangnya dalam durasi 


\begin{tabular}{llrr}
\hline \hline Volume: & 3 & E-ISSN: & $2655-1942$ \\
Number: & 1 & Terbitan: & Juni 2020 \\
Page : & $142-168$ & & \\
\hline
\end{tabular}

dua tahun yang dihitung sejak pasien mulai berobat. Pemusnahan data rekam medik baru dapat dilaksanakan pasca dua tahun masa daluwarsa tersebut. Mencermati mengenai konten yang ada di dalam data rekam medis mengandung urgensi serta resiko yang sangat besar terhadap diri pribadi pasien dan kode etik kedokteran. Sehingga pengelolaan den penggunaannya dibatasi hanya untuk kepentingan pengobatan pasien. Namun sangat disayangkan dalam sejumlah kasus yang terjadi menunjukan adanya kebocoran data medik terutama dua pasien awal serta petugas medis yang bertugas melakukan perawatan pada Pasien yang positif terjangkit Virus Covid-19 . Kebocoran rekam medis yang terungkap di hadapan public sejatinya menunjukan kelemahan pengawasan pengelolaan Lembaga jasa layanan Kesehatan.

Rekam medis ini bersifat rahasia dan terbatas, maka dokter selaku pihak penyelenggara jasa Kesehatan secara professional bertanggung jawab untuk menjaga dan mengelola dengan baik. Secara tidak langsung kerahasiaan rekam medis terikat dengan rahasia jabatan profesi dokter. Penyampaian isi Rekam medis kewenangannya hanya dapat dilakukan oleh dokter yang melakukan Tindakan medis terhadap pasien yang bersangkutan. Kerahasiaan data rekam medis merupakan hak individual bagi setiap pasien, sekaligus kewajiban bagi petugas penyelenggara jasa layanan Kesehatan untuk menyimpan rahasia jabatan. Pengamanan data rekam medis tidak hanya menyangkut martabat hak asasi pasien Covid-19 semata, namun juga terkait rahasia jabatan profesi seorang penyedia jasa layanan Kesehatan.

Instrumen hukum yang mengatur mengenai jaminan perlindungan keamanan data rekam medis pasien dalam ketentuan pada Pasal 79 huruf b UU Praktik Kedokteran yang merumuskan pemberlakuan sanksi pidana yang menyebutkan bahwa: “

Dipidana dengan pidana kurungan paling lama 1 (satu) tahun atau denda paling banyak Rp50.000.000,00 (lima puluh juta rupiah), seap dokter atau dokter gigi yang: dengan sengaja tidak membuat rekam medis sebagaimana dimaksud dalam Pasal 46 ayat (1)

Namun ketentuan pidana yang dikenakan pada dokter yang melakukan pelanggaran dicabut melalui Putusan Mahkamah Konstitusi RI No. 4 /PUU-V/2007 yang menyatakan bahwa Pasal 75 Ayat (1) dan Pasal 76 sepanjang mengenai kata-kata penjara paling lama 3 (tiga) tahun 


\begin{tabular}{llrr}
\hline \hline Volume: & 3 & E-ISSN: & $2655-1942$ \\
Number: & 1 & Terbitan: & Juni 2020 \\
Page : & $142-168$ & & \\
\hline
\end{tabular}

atau dan Pasal 79 sepanjang mengenai kata-kata kurungan paling lama 1 (satu) tahun atau serta Pasal 79 huruf c sepanjang mengenai kata-kata atau huruf e dalam UU Praktek Kedokteran dinyatakan MK bertentangan dengan Undang-Undang Dasar Negara 1945 dan dinyatakan tidak mempunyai kekuatan hukum yang bersifat mengikat. ${ }^{14}$

Dalam amar putusan nya, Mahkamah Konstitusi Republik Indonesia berpendapat bahwa logika kriminalisasi sanksi kurungan dan penjara dalam UU Praktek Kedokteran, jika dikaji dengan teori filsafat hukum sangat tidak proporsional dan berpotensi menimbulkan intimidasi bagi para dokter dalam menjalankan profesinya . Hal ini dapat berimplikasi pada penurunan pelayanan kesehatan pada masyarakat, sehingga kebijakan kriminalisasi pada UU praktek kedokteran berpotensi berbenturan dengan Hak Asasi dalam Pasal 28H ayat (1) UUD 1945 yang menyatakan bahwa setiap orang berhak memperoleh pelayanan kesehatan.

Demi mengantisipasi kekosongan Hukum dalam hal penerapan sanksi terhadap para pelanggar Batasan keterbukaan informasi public, maka dasar Hukum yang digunakan untuk memberikan sanksi adalah asal 54 UU Keterbukaan Informasi Publik yang menyatakan bahwa : Setiap orang yang dengan sengaja dan tanpa hak mengakses dan/atau memperoleh, memberikan informasi yang dikecualikan dipidana dengan pidana penjara paling lama 2 tahun dan pidana denda maksimal Rp10 juta. Dengan adanya aturan norma ini , maka setiap pelanggaran atas informasi bersifat pribadi dapat dikenakan sanksi hukum sesuai peraturan perundangan-undang ini.

Komisi Informasi Pusat juga mengeluarkan panduan tambahan agar mencegah terjadinya penyalahgunaan data pribadi subjek yang positif terjangkit Covid-19 yaitu menerbitkan Surat Edaran Nomor: 2 Tahun 2020 tentang Pelayanan Informasi Publik Dalam Masa Darurat Kesehatan Masyarakat akibat Covid-19. Surat Edaran ini mengatur Batasan data yang boleh layanan informasi terkait Covid-19 yang meliputi : jenis penyakit, persebaran, area episentrum, serta pencegahan nya. Penyampaian informasi dilakukan secara ketat dan terbatas dengan tetap

\footnotetext{
${ }^{14}$ Baca Putusan Mahkamah Konstitusi RI No. 4/PUU-V/2007 tentang Praktek Kedokteran
} 


\begin{tabular}{llrr}
\hline \hline Volume: & 3 & E-ISSN: & $2655-1942$ \\
Number: & 1 & Terbitan: & Juni 2020 \\
Page : & $142-168$ & & \\
\hline
\end{tabular}

melindungi data pribadi Orang Dalam Pemantauan (ODP), Pasien Dalam Pengawasan (PDP), Pasien Positif dan orang yang dinyatakan sembuh.

\subsection{Implikasi dan Tantangan Hukum Dalam Menangani Penentuan Prioritas} Kepentingan Antara Keterbukaan dan Perlindungan Kerahasiaan Data Pasien Pada Masa Pandemic Covid-19

Pertentangan mengenai keterbukaan informasi public dengan membebaskan hak akses data rekam medis pribadi pasien positif Covid-19 menjadi isu hukum yang mengemuka pada masa pandemic ini . Puncak momentum ini terjadi ketika ada warga negara yang mengajukan judicial review ke Mahkamah Konstitusi (MK) untuk menguji norma - norma Hukum pada sejumlah aturan perundang-undangan yang menetapkan strata klasifikasi data milik pasien. Hal ini bertujuan untuk membuat langkah reaktif penanggulangan sejak dini dengan mengetahui kondisi medis pasien penderita atau terduga Positif Covid-19.

Pada akhir Bulan Maret 2020, Advokat Muhammad Sholeh beserta enam kolega nya mewakili dua klien nya untuk mendaftarkan permohonan uji materi sejumlah Undang-Undang yang berkaitan dengan kerahasiaan data pasien Covid-19 ke Mahkamah Konstitusi melalui pendaftaran online. ${ }^{15}$ Para pemohon merasa Hak Konstitusi nya terganggu akibat pemberlakuan Pasal-Pasal yang melindungi data pribadi yang berpotensi merugikan kepentingan masyarakat. Menurut pendapat subyektif nya pemohon menilai eksistensi pasal-pasal perlindungan data pribadi menghalangi kepentingan konstitusional para pemohon guna informasi mengenai pasien yang sudah terkena Covid-19. Jika informasi itu dibuka, dapat meminimalisir resiko lebih cepat.

Peristiwa diatas menunjukan adanya ketenggangan antara hak asasi pasien positif atau terduga Covid-19 yang harus dilindungi secara hukum dengan hak asasi publik yang menuntut agar lebih terlindungi dari penyebaran wabah Covid-19. Pengecualian untuk mempublikasikan informasi data rekam medis pasien secara hukum telah memiliki dasar pelindungan dalam

15 Artikel Kontroversi Kerahasiaan Data Pasien Covid-19, Advokat Ini Daftarkan Uji Materi ke MK, https://www.hukumonline.com/berita/baca/lt5e79914cdc110/kontroversi-kerahasiaan-data-pasien-covid-19-advokat-ini-daftarkan-uji-materi-ke-mk diakses pada tanggal 31 Mei 2020 pada pukul 08.00 WIB 


\begin{tabular}{llrr}
\hline \hline Volume: & 3 & E-ISSN: & $2655-1942$ \\
Number: & 1 & Terbitan: & Juni 2020 \\
Page : & $142-168$ & & \\
\hline
\end{tabular}

sejumlah ketentuan yaitu Pasal 17 h UU KIP serta Pasal 57 ayat (1) UU Nomor 36 Tahun 2009 tentang Kesehatan, yang menyatakan bahwa setiap orang berhak atas rahasia kondisi kesehatan pribadinya yang telah dikemukakan kepada penyelenggara pelayanan kesehatan.

Suatu produk hukum dikatakan berhasil, apabila tiga unsur dalam system hukum mampu bersinergi dengan baik . Menurut Lawrence M. Friedman, dalam setiap sistem hukum terdiri dari 3 (tiga) sub sistem, yaitu sub system substansi hukum (legal substance), sub sistem struktur hukum (legal structure), dan subsistem budaya hukum (legal culture). ${ }^{16}$ Substansi Hukum adalah materi Hukum yang dirumuskan dalam Undang-Undang. Berkaitan dengan norma pengaturan data pribadi / rekam medis pasien positive Covid-19, ditemukan dua buah substansi norma hukum yang dapat menjadi celah gugatan yang secara tidak langsung menunjukan kelemahan perlindungan instrument hukum, diantaranya :

\section{1). Disharmonisasi ketentuan Pasal 57 ayat (1) dengan Pasal 52 UU Kesehatan.}

Dalam ketentuan Pasal 57 ayat (2) dinyatakan bahwa sifat kerahasiaan data pribadi ini tidak berlaku terhadap sejumlah hal diantaranya: perintah Undang-Undang, perintah pengadilan, izin yang bersangkutan, kepentingan masyarakat; dan kepentingan orang tersebut. Benturan norma dalam Undang-Undang Kesehatan ini bisa dijadikan celah hukum bagi pihak yang menginginkan pembukaan informasi pasien Covid-19 ke publik dengan dalih argument yang menyatakan bahwa pandemi Covid-19 sudah mengancam kepentingan masyarakat, mengancam kesehatan masyarakat, dan penularannya sudah sedemikian mengkhawatirkan.

\section{2). Dihapusnya Delik Pidana Dalam UU Praktek Kedokteran oleh Putusan MK}

Penghapusan delik pidana sebagaimana tertuang dalam Pasal 79 c UU Praktek Kedokteran terhadap Dokter yang tidak menjalankan kewajiban. Pasal $51 \mathrm{c}$ terdapat kewajiban dokter untuk merahasiakan informasi mengenai Kesehatan pasien hingga si pasien meninggal. Dengan adanya penghapusan kebijakan kriminalisasi terhadap dokter, bilamana terjadi kelalaian pembukaan

\footnotetext{
${ }^{16}$ Lawrence M. Friedman, Hukum Amerika: Sebuah Pengantar, Terjemahan dari American Law An Introduction, 2nd Edition, Alih Bahasa: Wisnu Basuki, Jakarta: Tatanusa, 2001,
} 


\begin{tabular}{llrr}
\hline \hline Volume: & 3 & E-ISSN: & $2655-1942$ \\
Number: & 1 & Terbitan: & Juni 2020 \\
Page : & $142-168$ & & \\
\hline
\end{tabular}

rekam medik oleh oknum dokter selaku penyelenggara jasa Kesehatan akan menimbulkan kesulitan dalam melakukan penindakan, karena basis hukum yang bersifat lex specialis telah dicabut. Dengan tidak adanay memiliki aturan yang bersifat spesifik dan jelas, potensi penyalahgunaan transfer informasi data rekam medis menjadi tidak terkendali dan meningkatkan kemungkinan kebocoran informasi serta aksesibilitas orang yang tidak berwenang. ${ }^{17}$ Problematika ini menjadi tantangan bagi manajemen penyedia jasa layanan Kesehatan dalam menjalankan peran dan tanggung jawab baru sebagai administrator data rekam medis

Merujuk pada kelemahan dari sisi substansi hukum tersebut, jika mengkaji tujuan hukum secara filosofis terhadap perlindungan Hukum dengan menggunakan teori Gustav Radbruch yang menyatakan terdapat tiga nilai dasar hukum yang menjadi tolak ukurannya yaitu kepastian Hukum, keadilan dan kemanfaatan. Dari sisi kepastian hukum, perbenturan / inkonsistensi ketentuan dalam UU Kesehatan menimbulkan ketidakpastian hukum dalam penegakan hukum untuk melindungi data rekam medis milik pasien positive Covid-19. Disharmonisai ini akan dijadikan celah untuk melemahkan kedudukan hukum terhadap hak kerahasiaan data rekam medik pasien. Sisi Keadilan menjadi grey area, karena dengan dicabutnya sanksi pidana dalam UU Praktek Kedokteran beresiko memperlemah hak pasien bilamana terjadi pelanggaran oleh oknum penyelenggara jasa Kesehatan berkaitan dengan data rekam medis. Kemanfaatan yang ingin dicapai sebagai landasan filosofi UU Kesehatan tidak dapat diterapkan secara maksimal.

Aspek kedua dalam system Hukum adalah Struktur Hukum. Menurut Lawrence Friedman , Struktur Hukum turut berperan dalam menentukan keberhasilan suatu produk hukum. Dalam penegakan hukum perlindungan atas data rekam medis pasien, Peranan Sentral Komisi Informasi Pusat (KIP) dan Komisi Informasi Provinsi dalam menangani sengketa informasi patut dianalisa, terutama berkaitan dengan Kewenangan pembuatan pedoman pelaksanaan pelayanan

\footnotetext{
${ }^{17}$ Mohammad Hossein Yarmohammadiana et al. Medical record information disclosure laws and policies among selected countries; a comparative study. Journal of Research in Medical Science May-Jun; 15(3):2010 p. 141
} 


\begin{tabular}{llrr}
\hline \hline Volume: & 3 & E-ISSN: & $2655-1942$ \\
Number: & 1 & Terbitan: & Juni 2020 \\
Page : & $142-168$ & & \\
\hline
\end{tabular}

informasi public sebagaimana diatur dalam UU No. 14 Tahun 2008 tentang Keterbukaan Informasi Publik.

Penanggulangan pandemic virus Covid-19, Komisi Informasi mempunyai tugas penting yaitu Pertama, Menyusun petunjuk teknis pelayanan informasi pada saat kondisi darurat . Rumusan ketentuan dalam UU No. 14 Tahun 2008 hanya mengatur pelayanan informasi pada saat negara dalam situasi normal, tidak dalam darurat bencana Nasional. Komisi indformasi sebaiknya Menyusun pedoman itu dilakukan sejak awal pandemi. Pada tataran ini, KIP telah menjalankan tugasnya dengan menerbitkan pedoman pelayanan informasi pada masa darurat kesehatan.

Kedua, mekanisme penyelesaian sengketa informasi yang cukup kompleks . Hingga kini belum ada permohonan penyelesaian sengketa yang berkenaan dengan data pribadi pasien Covid-19. Jika ada, permohonan pihak yang dirugikan harus diajukan terlebih dahulu ke Badan Publik yang mengontrol data pasien yang dipublikasikan . Jika ada permintaan, maka Badan Publik tersebut wajib melakukan uji kepentingan publik. Parameter pengujian yang digunakan menerapkan dua pengandaian yaitu apakah akibat hukumnya jika informasi dibuka dan apakah dampaknya jika informasi tetap menjadi rahasia secara hukum

Berdasarkan dua indicator ini Badan Publik melakukan penilaian keseimbangan kepentingan. Jika ada pemohon informasi yang keberatan dengan hasil tes kepentingan tersebut, setelah melalui mekanisme yang diatur UU Keterbukaan Informasi Publik, pemohon data pasien dapat mengajukan permohonan sengketa informasi kepada Komisi Informasi Pusat atau Komisi Informasi Provinsi yang berwenang.

Tinjauan dari budaya hukum terhadap perlindungan rekam medis pasien pribadi pasien Covid-19, pemahaman masyarakat akan pentingnya data rekam medis sebagai sutu privasi belum begitu optimal. Literasi masyarakat mengenai Batasan info yang boleh dipublikasikan secara umum belum dipahami betul-betul oleh masyarakat, seperti terhadap pembukaan informasi pribadi dua pasien pertama positif Covid-19 yang berujung pada perlakuan 


\begin{tabular}{llrr}
\hline \hline Volume: & 3 & E-ISSN: & $2655-1942$ \\
Number: & 1 & Terbitan: & Juni 2020 \\
Page : & $142-168$ & & \\
\hline
\end{tabular}

diskriminasi dan justifikasi secara sepihak kepada pihak yang bersangkutan maupun anggota keluarganya. Ketiga indicator system hukum diatas menunjukan belum komprehensif nya perlindungan yang diberikan secara hukum terhadap pelindungan data pribadi pasien pengidap Covid-19.

\section{Evaluasi Untuk Menengahi Konflik Keterbukaan Informasi dengan Perlindungan Ha atas Privasi Data Medis Pasien Covid-19}

Penyebaran pandemic Virus Covid-19 yang telah menjalar hampir ke seluruh negara di dunia, mendorong banyak kepala pemerintah mengambil kebijakan yang tidak konvensional untuk membendung, memberantas dan meminimalisasi resiko penyebaran Covid-19 melalui penggunaan informasi data. Penggunaan system Digitalis difungsikan untuk mengumpulkan \, memproses dan mengalihkan data guna membentuk jaringan informasi yang tersusun secara terintegrasi .

Langkah moderat yang diambil Pemenintah sejumlah negara menggunakan pemanfaatan data guna menyebarluaskan informasi aktual yang akan digunakan untuk pemetaan kebijakan yang berkesinambungan dalam penanganan Wabah Covid-19. Sejumlah terobosan kebijakan dicanangkan oleh masing-masing negara untuk mengatasi bencana penyakit ini. Salah satu Langkah kontroversial adalah penggunaan akses data pribadi yang berisiko melanggar privasi dan hak-hak dasar warga negaranya. Otoritas penegakan privasi pada umumnya mendukung pendekatan pragmatis dan kontekstual dalam menangani keadaan darurat akibat wabah covid-19 dengan tetap memperhatikan proporsionalitas dan penghormatan terhadap prinsip-prinsip privasi masyarakat,

Pengambilan sebagian data privasi digunakan untuk menilai dan meningkatkan kapasitas sistem perawatan Kesehatan dan untuk mengevaluasi efektivitas kebijakan penahanan dan mitigasi yang membatasi pergerakan individu. ${ }^{18} \mathrm{Hal}$ ini menimbulkan tantangan baru terhadap

18 Ensuring data privacy as we battle COVID-19 diakses dalam http://www.oecd.org/coronavirus/policyresponses/ensuring-data-privacy-as-we-battle-covid-19-36c2f31e/ pada tanggal 1 Juni 2020 pukul 09.00 WIB 


\begin{tabular}{llrr}
\hline \hline Volume: & 3 & E-ISSN: & $2655-1942$ \\
Number: & 1 & Terbitan: & Juni 2020 \\
Page : & $142-168$ & & \\
\hline
\end{tabular}

Kelola dan keamanan privasi. Contohnya adalah dengan cara penelusuran kontak pribadi yang digunakan dalam memberikan informasi penting dalam membatasi persebaran virus, namun di satu sisi berpotensi menimbulkan pengumpulan dan pembagian data pribadi secara massal, pengekangan kebebasan individu dan men disrupsi Hak demokrasi masyarakat.

Beberapa negara memiliki solusi terukur guna mendukung langkah-langkah luar biasa untuk mengulangi wabah Covid-19 dengan tetap memperhatikan peraturan privasi dan perlindungan data , berikut ini : ${ }^{19}$

- Otoritas Republik Korea mempunyai wewenang luar biasa untuk mengumpulkan data pribadi jika "diperlukan untuk mencegah penyakit menular dan memindahkan infeksi" (Undang-Undang Pengendalian dan Pencegahan Penyakit Menular, Pasal 76-2).

- Di Singapura, data pribadi yang relevan dapat dikumpulkan, digunakan, dan dikumpulkan tanpa persetujuan untuk pembayaran kontak dan tindakan tanggapan lainnya.

Berdasarkan praktik pengumpulan data dalam penanganan Covid-19 pada sejumlah negara diatas, Pemerintah negara-negara tersebut sama sekali tidak membuka identitas pribadi dari pasien positif COVID-19, terutama yang masih berstatus suspect. Pemerintah cukup memberikan nomor bagi pasien yang positif atau terduga terjangkit berdasarkan pada nomor urut identifikasi kasusnya. Alasan untuk melindungi kesehatan public dapat dimungkinkan melalui pembatasan terhadap perlindungan data pribadi ini dengan tetap memperhatikan sejumlah persyaratan, misalnya persetujuan yang jelas dari subjek data, dan ditujukan untuk kepentingan vital dari subjek data.

Dalam praktik negara-negara seperti Korea Selatan dan Singapura diatas, keduanya mempunyai dasar hukum berupa UU perlindungan data Pribadi yang kuat . Sehingga meskipun ada kebijakan untuk mengakses data pribadi pasien yang diduga atau telah terinfeksi Covid-19 ( Contact Tracing), ruang lingkup data pribadi yang ditelusuri meliputi rekam jejak aktivitas

${ }^{19}$ Ibid 


\begin{tabular}{llrr} 
Volume: & 3 & E-ISSN: & $2655-1942$ \\
Number: & 1 & Terbitan: & Juni 2020 \\
Page : & $142-168$ & & \\
\hline
\end{tabular}

yang mempunyai korelasi dengan penularan dan lokasi yang dikunjungi selama kurang lebih 14 hari tanpa membuka identitas pribadi pasien.

Di satu sisi Langkah ini dinilai cukup fair, karena manfaat bisa menghasilkan efek yang positif untuk menekan tingkat penularan dengan memberikan informasi kepada publik yang berpotensi berkontak langsung dengan pasien. Meskipun demikian Penyebaran informasi dan status rekam medis pasien tetap tidak diperkenankan untuk dibuka pada khalayak umum, kecuali mendapatkan persetujuan yang jelas dari pemilik data dan kepentingan vital dari subjek data.

Pemerintah Indonesia dapat mengadopsi praktik penggunaan data pribadi baik oleh pemerintah didasarkan pada Prinsip Pelindungan Data Pribadi, yaitu prinsip proporsionalitas , necessities dan purposive limitation. Prinsip purposive limitation merupakan ketentuan batas pengumpulan data pribadi dan data tersebut harus diperoleh dengan cara yang sah serta adil dan bila perlu, dengan sepengetahuan atau persetujuan dari subyek data. ${ }^{20}$ Konten data pribadi yang telah dikumpulkan hanya dapat digunakan secara terbatas untuk berkaitan dengan kebijakan penanggulangan COVID-19, Dengan terlebih dahulu mendapatkan persetujuan jelas dari pasien yang bersangkutan tanpa mempublikasikan profil pribadi .

\section{Kesimpulan}

Berdasarkan hasil penelitian diatas, artikel ini menemukan beberapa kesimpulan yang terdiri dari; Data Rekam Medis Pasien dikategorikan oleh sejumlah peraturan Undang-Undang sebagai Hak individu yang bersifat privat dan rahasia, sehingga tidak bisa dipublikasikan kepada umum tanpa persetujuan pihak pasien yang bersangkutan., Sejumlah Peraturan perundangundangan secara terpisah telah mengatur tentang perlindungan data rekam medis pasien , Namun belum cukup optimal. Hal ini disebabkan adanya pertentangan norma dalam UU Kesehatan antara Pasal 71 dan Pasal 72 yang menimbulkan ketidakpastian secara hukum dan dihapuskan nya sanksi pidana bagi oknum dokter yang melakukan pelanggaran atas hak rekam medis turut merugikan posisi pasien dalam perjanjian terapeutik, Praktik penelusuran data

\footnotetext{
${ }^{20}$ Abu Bakar Munir et al Data Protection Law in Asia, (Hong Kong, Thompson Reuters Limited 2014) p.35
} 


\begin{tabular}{llrr}
\hline \hline Volume: & 3 & E-ISSN: & $2655-1942$ \\
Number: & 1 & Terbitan: & Juni 2020 \\
Page : & $142-168$ & & \\
\hline
\end{tabular}

pribadi pasien dapat dimungkinkan dilakukan di Indonesia dengan memperhatikan proporsionalitas, Batasan dan kebutuhan yang berkaitan dengan pembatasan penyebaran Wabah Covid19. Selain itu Rancangan Undang-Undang tentang perlindungan data Pribadi seyogyanya lekas disahkan agar Indonesia mempunyai regulasi payung utama yang digunakan sebagai jembatan untuk menangani pengaturan parsial data pribadi yang tersebar dalam sejumlah regulasi .

\section{DAFTAR PUSTAKA}

\section{Buku:}

Abdul Kadir Muhammad. Hukum Dan Penelitian Hukum. Bandung : PT. Citra Aditya.2015

Lawrence M. Friedman, Hukum Amerika: Sebuah Pengantar, Terjemahan dari American Law An Introduction, 2nd Edition, Alih Bahasa: Wisnu Basuki, Jakarta: Tatanusa, 2001 ;

Sudikno Mertokusumo, Mengenal Hukum Suatu Pengantar, Yogyakarta: Liberty, 2005

\section{Jurnal:}

Abu Bakar Munir iti Hajar Mohd Yasin, Md. Ershadul Karim, Data Protection Law in Asia, (Hong Kong, Thompson Reuters Limited 2014)

Anny Retnowati. Tinjauan Hukum Terhadap rekam Medis," JUSTITIAETPAX, (26), No. 1 .Juni 2006

Anny Retnowati. Politik Hukum dalam Menata Rekam Medis sebagai alt perlindungan Hukum Terhadap Rumah Sakit, Dokter dan Pasien . Jurnal Yustisia Vol.2 No.2 Mei -Agustus 2013

Chan Khung Wang. Security and privacy of Personal Health Record, Electronic Medical Record and Health Information. Problems and Perspectives in Management, Volume 13, Issue 4, 2015

Endang Wahyati Yustina . Hak atas Informasi Publik dan Hak atas Rahasia Medis : Problem Hak Asasi Manusia dalam Pelayanan Kesehatan . Padjajaran Jurnal Ilmu Hukum. Vol 1 No.2 tahun 2014

Mohammad Hossein Yarmohammadiana, Ahmad Reza Raeisi*b, Nahid Tavakolic, Leila Ghaderi Nansad. Medical record information disclosure laws and policies among selected countries; a comparative study. Journal of Research in Medical Science May-Jun; 15(3):2010

Sudjana, Aspek Hukum Rekam Medis atau Rekam Medis Elekronik Sebagai Alat Bukti Dalam Transksi Elektronik. Jurnal Veritas et Justitia Volume 3 Nomor 2 , Penerbit ; Fakulats Hukum Universitas Katolik Parahyangan 
Law, Development \& Justice Review

\begin{tabular}{llrr}
\hline Volume: & 3 & E-ISSN: & 2655-1942 \\
Number: & 1 & Terbitan: & Juni 2020 \\
Page : & $142-168$ & &
\end{tabular}

Sinta Dewi Rosadi . Implikasi Penerapan Program E-Health Dihubungakn Dengan Perlindungan Data Pribadi . Jurnal Arena Hukum Volume 9, Nomor 3, Desember 2016.

\section{Undang-Undang}

UU. No.29 Tahun 2004 tentang Praktek Kedokteran

UU No. 14 Tahun 2008 tentang Keterbukaan Informasi Publik.

UU. No. 44 tahun 2009 tentang Rumah Sakit

UU Nomor 36 Tahun 2009 tentang Kesehatan

UU No. 36 Tahun 2014 Tentang Tenaga Kesehatan

Permenkes No. 269/Menkes/Per/III/2008 tentang Rekam Medis

Surat Edaran Nomor: 2 Tahun 2020 tentang Pelayanan Informasi Publik Dalam Masa Darurat Kesehatan Masyarakat akibat Covid-19

\section{Putusan Pengadilan}

Putusan Mahkamah Konstitusi Republik Indonesia No.4 /PUU-V/2007 tentang Praktek

Kedokteran

\section{Website}

Artikel Kontroversi Kerahasiaan Data Pasien Covid-19, Advokat Ini Daftarkan Uji Materi ke MK, https://www.hukumonline.com/berita/baca/lt5e79914cdc110/kontroversi-kerahasiaandata-pasien-covid-19--advokat-ini-daftarkan-uji-materi-ke-mk

Data Kementerian Kesehatan RI tentang Persebaran Penyakit Virus Covid 19 per April 2020 dalam https://covid19.kemkes.go.id/situasi-infeksi-emerging/info-corona-virus/situasiterkini-perkembangan-coronavirus-covid-19-6-april-2020/\#.XtUc_TozbIW yang diakses pada Sabtu 30 Mei 2020 pukul 23.00 WIB

Data Persebaran Virus Covid 19 Mei 2020 yang diakses dari https://covid19.kemkes.go.id/situasi-infeksi-emerging/info-corona-virus/situasi-terkiniperkembangan-coronavirus-disease-covid-19-31-mei-2020/\#.XtcJYTozbIU pada 31 Mei 202

Ensuring data privacy as we battle COVID-19 diakses dalam http://www.oecd.org/coronavirus/policy-responses/ensuring-data-privacy-as-we-battlecovid-19-36c2f31e/

https://health.detik.com/berita-detikhealth/d-4922758/kronologi-2-pasien-pertama-virus-coronacovid-19-di-indonesia/1 diakses pada 30 Mei 2020 pukul 20.00 WIB 